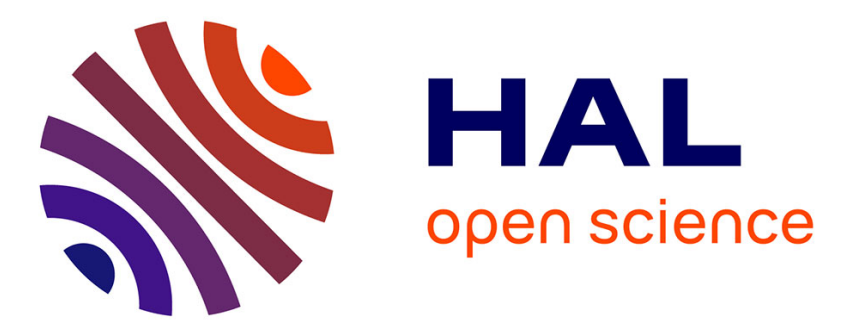

\title{
Circulating sphingosine-1-phosphate inversely correlates with chemotherapy-induced weight gain during early breast cancer
}

\author{
Dmitri Pchejetski, Joao Nunes, Lysann Sauer, Jasmin Sidhu, Anand Sharma, \\ Hector C. Keun, Jonathan Waxman, Justin Stebbing
}

\section{To cite this version:}

Dmitri Pchejetski, Joao Nunes, Lysann Sauer, Jasmin Sidhu, Anand Sharma, et al.. Circulating sphingosine-1-phosphate inversely correlates with chemotherapy-induced weight gain during early breast cancer. Breast Cancer Research and Treatment, 2010, 124 (2), pp.543-549. 10.1007/s10549010-0968-y . hal-00545275

\section{HAL Id: hal-00545275 \\ https://hal.science/hal-00545275}

Submitted on 10 Dec 2010

HAL is a multi-disciplinary open access archive for the deposit and dissemination of scientific research documents, whether they are published or not. The documents may come from teaching and research institutions in France or abroad, or from public or private research centers.
L'archive ouverte pluridisciplinaire HAL, est destinée au dépôt et à la diffusion de documents scientifiques de niveau recherche, publiés ou non, émanant des établissements d'enseignement et de recherche français ou étrangers, des laboratoires publics ou privés. 
Article type: Short communication

\title{
Circulating sphingosine-1-phosphate inversely correlates with chemotherapy induced weight gain during early breast cancer
}

\author{
Dmitri Pchejetski*1, Joao Nunes ${ }^{1}$, Lysann Sauer ${ }^{1}$, Jasmin Sidhu ${ }^{2}$, Anand Sharma ${ }^{2}$, \\ Hector C. Keun ${ }^{2}$, Jonathan Waxman ${ }^{1}$, Justin Stebbing ${ }^{1}{ }^{1}$
}

1. Department of Surgery and Cancer, Imperial College, London, UK

2. Biomolecular Medicine, Department of Surgery and Cancer, Imperial College, London, UK

Running head: S1P in chemotherapy-induced weight gain

* To whom correspondence should be addressed:

\begin{tabular}{|l|l|}
\hline $\begin{array}{l}\text { Dr. Dmitry Pshezhetskiy } \\
\text { Department of Oncology } \\
\text { Imperial College London }\end{array}$ & $\begin{array}{l}\text { Dr. Justin Stebbing } \\
\text { Imperial College Healthcare NHS Trust }\end{array}$ \\
$\begin{array}{l}\text { 501, Cyclotron building } \\
\text { Charing Cross Hospital, 1st Floor, E } \\
\text { Wing, Fulham Palace Road, } \\
\text { Ducane road, W120NN }\end{array}$ & $\begin{array}{l}\text { London, W6 8RF } \\
\text { London, UK }\end{array}$ \\
$\begin{array}{l}\text { Tel: }+442033118295 \\
\text { Tel: +44 (0) } 2083838043 \\
\text { Fax: +44 (0) } 2083835830\end{array}$ & Fax: +44 208 846 1433 \\
e-mail: d.pshezhetskiy@imperial.ac.uk & \\
& \\
\hline
\end{tabular}




\section{Abstract}

Background: Weight gain in women receiving chemotherapy for breast cancer is associated with a higher risk of recurrence. Using metabonomic profiling, we recently reported that plasma lactate and alanine were prognostic for weight gain in individuals with breast cancer receiving chemotherapy. The role of lipid second messengers have not been studied.

Methods: We assessed serum levels of sphingosine-1-phosphate (S1P), a known secreted lipid second messenger with a role in cell growth, in sequential samples from postmenopausal women receiving standard chemotherapy for early breast cancer and correlated these with body mass measurements and metabonomic profiling.

Results: While serum S1P levels prior to treatment did not correlate with body weight changes or circulating alanine and lactate, S1P levels measured during therapy were inversely correlated with weight gain $(\mathrm{p}=0.04)$, but not weight loss $(\mathrm{p}=0.74)$ or no change in weight ( $\mathrm{p}=0.5$ ), suggesting a role of dynamic circulating S1P in adipocyte growth.

Conclusions: These data provide evidence for an association between serum S1P and weight gain during chemotherapy cycles in women with breast cancer. Lipid second messengers have a role in chemotherapy induced weight gain in breast cancer.

Keywords: Breast cancer, Weight, Chemotherapy, Sphingosine-1-phosphate. 


\section{Introduction}

Weight gain remains a common problem among patients with early breast cancer who receive chemotherapy $[1,2]$. However, three decades since the original reports [3-5], we are no closer to understanding the mechanisms involved although its detrimental effects have been increasingly noted. Weight gain adversely affects quality of life and leads to cardiovascular disorders, hypertension, diabetes and orthopedic problems. Interestingly, those individuals who gain the most weight appear to have an increased incidence of local and/or distant recurrence of breast cancer [6-9]. In addition, there is strong evidence for reduced response to neoadjuvant chemotherapy and poorer survival in overweight and obese breast cancer patients [10]. These findings were supported by interim data from the Women's Intervention Nutrition Study (WINS) in which women with early breast cancer randomized to dietary intervention resulting in weight loss had a decreased relapse-free survival, an effect most marked in women with estrogen receptor negative breast cancers [11].

In a further recent study, women who ate more vegetables and exercised had an improved survival [12]. In a recent study, we used metabonomic analyses in women with breast cancer to identify circulating levels of lactate and alanine as prognostic markers for chemotherapyinduced weight gain [13].

S1P, a lipid second messenger with paracrine and autocrine functions is generated by sphingosine kinase $1(\mathrm{SphK} 1)$, is a potent chemokine and a mediator of processes with important roles in cell growth [14]. S1P pools in the extracellular milieu [15] and once secreted it engages specific G-protein-coupled receptors (S1PRs) [16]; all five S1PRs have diverse effects on cell proliferation and survival [17] which largely depend on the level of 
expression and cell type [18]. The SphK1/S1P pathway has been associated with many signaling pathways including TNF [19], cyclooxygenase 2/prostaglandin E2 [20], ERK1/2 and others [21]. There is compelling evidence that aberrant activation of the SphK1/S1P pathway contributes to cancer progression. SphK1 has been found to be a tumor-associated enzyme: high levels of SphK1 expression have been shown in various human tumor tissues such as brain, breast, colon, lung, ovary, stomach, uterus, kidney, rectum and small intestine $[22,23]$. High levels of SphK1 expression and activity is associated with a poor prognosis in breast cancer [24], glioblastoma multiforme [25], astrocytoma [26] and gastric cancer [27].

The major sources of circulating S1P are platelets $[28,29]$ and erythrocytes $[30,31]$. The potential of S1P to have a role as a serum marker of human disease has been recently demonstrated in a study which showed that an elevated concentration of S1P in patients' serum was associated with inflammatory coronary artery disease [32]. Circulating levels of S1P were also associated with murine colon cancer [33] or human ovarian cancer (although no difference between stages was observed) [34], and S1P receptor antagonists are in a wide variety of clinical trials.

To gain further insights into the mechanism(s) that control the changes in weight observed in women with breast cancer receiving chemotherapy, we measured circulating levels of S1P in individuals prior to, and during chemotherapy cycles [13] and correlated them to parameters related to body mass. In this current report, we show that serum S1P levels measured during chemotherapy had a strong inverse correlation with weight gain, but not with weight loss or no change. While circulating S1P was not identified as a prognostic marker for chemotherapy-induced weight gain, these data suggest a role for S1P involvement in the regulation of adipocyte growth during cancer chemotherapy. 


\section{Materials and Methods}

\section{Patients and Sample Collection}

Serum samples were obtained from 21 post-menopausal women before and during each cycle of chemotherapy for breast cancer, in either the adjuvant or neo-adjuvant settings; a total of 126 samples were collected (suppl. Table 1). All patients received 5-fluorouracil $\left(500 \mathrm{mg} / \mathrm{m}^{2}\right)$ cyclophosphamide $\left(500 \mathrm{mg} / \mathrm{m}^{2}\right)$ and epirubicin $\left(75 \mathrm{mg} / \mathrm{m}^{2}\right)$ based chemotherapy every 3 weeks intravenously. Standard anti-emetics with ondansetron and domperidone were administered. In all cases, samples were obtained immediately prior to each 3 weekly cycle of chemotherapy (thus the baseline sample was taken at cycle 1, the final sample 18 weeks later at cycle 6). Patients' weights were obtained using a Tanita BC-418 pro-segmental bodyfat analyser, which was kindly loaned to us for this study (Tanita UK Ltd, West Drayton, UK). This measures body composition with a validated 4-compartment model as recently described [35]. We asked subjects not to eat for 2 hours prior to measurement, and empty their bladder before the start of the measurements. Subjects were weighed in their underwear; these readings were obtained immediately prior to the blood draw and automatically saved in a dedicated computer. Height was measured to the nearest $5 \mathrm{~mm}$ using a wall-mounted stadiometer and the body mass index was calculated. At the time of writing, outcome measures including survival or recurrence of the patients were unknown and no relapses had occurred.

\section{Reagents}

$\left[\gamma_{-}{ }^{32} \mathrm{P}\right]$-ATP $(6,000 \mathrm{mCi} / \mathrm{mmol})$ was purchased from Perkin-Elmer (Beaconsfield, UK), and silica gel 60 high-performance TLC plates were from the LabWarehouse (London, UK). All other chemicals and reagents were obtained from Sigma-Aldrich (Dorset, UK).

\section{Serum S1P analysis}


Intracellular S1P content was measured as described by Edsall et al. [36], and by ourselves [37]. Briefly, S1P was extracted from serum using alkaline chloroform/methanol extraction (Folch extraction [38]). To the aqueous phase, Folch extraction buffer C (200mM Tris-HCl, $\mathrm{pH} 7.4,75 \mathrm{mM} \mathrm{MgCl} 2$ in $2 \mathrm{M}$ Glycine, $\mathrm{pH} 9.0)$ was added (1:6, v/v) and $\mathrm{S} 1 \mathrm{P}$ was dephosphorylated by addition of $50 \mathrm{U} / \mathrm{sample}$ of alkaline phosphatase for $30 \mathrm{~min}, 37^{\circ} \mathrm{C}$. The reaction was stopped by addition of hydrochloric acid, and the organic phase containing sphingosine was separated and evaporated. Evaporated sphingosine was resuspended in 'SphK1' buffer (20 mM Tris-HCl, pH 7.4, 20\% glycerol, $1 \mathrm{mM} \beta$-mercaptoethanol, $1 \mathrm{mM}$ EDTA, $1 \mathrm{mM}$ sodium orthovanadate, $40 \mathrm{mM} \beta$-glycerophosphoate, $15 \mathrm{mM} \mathrm{NaF}, 10 \mathrm{mg} / \mathrm{ml}$ leupeptin, $10 \mathrm{mg} / \mathrm{ml}$ aprotinin, $10 \mathrm{mg} / \mathrm{ml}$ soybean trypsin inhibitor, $1 \mathrm{mM}$ phenylmethylsulfonyl fluoride, and $0.5 \mathrm{mM}$ 4-deoxypyridoxine) with $0.25 \%$ Triton $\mathrm{X}-100$. Sphingosine was converted to S1P by addition of cytosolic extracts of SphK1overexpressing PC-3 cells [39] and [ $\gamma$-32P]-ATP (10 mCi, $1 \mathrm{mM})$ containing 10mM MgCl2. The resulting ${ }^{32} \mathrm{P}-\mathrm{S} 1 \mathrm{P}$ was resolved by thin layer chromatography on silica gel 60 with 1 butanol/ethanol/acetic acid/water (80:20:10:10, v/v) and quantified by autoradiography. S1P content was expressed as picomoles of S1P formed/mg of serum protein.

\section{Data representation and statistical analysis}

We wished to measure serum levels of S1P with a given amount of confidence $(95 \%)$ comparing different groups of patients and correlating it to weight changes. All correlation analyses were performed using Pearson correlation test, normal distribution of the samples was confirmed using Kolmogorov-Smirnov test. The statistical significance of differences between the means of two groups was evaluated by the unpaired two-tailed t test. When three or more groups were analyzed, one-way Anova test has been used; all calculations were performed using Graphpad Prism Software. The role of S1P in weight gain was prespecified at baseline and during treatment, to avoid large numbers of statistical comparisons. 


\section{Results}

\section{Basal Circulating levels of S1P do not correlate with age, weight, BMI or weight change} Table 1 demonstrates correlations between basal levels of circulating S1P, body mass measurements and age. Serum S1P measured prior to chemotherapy had no correlation with any of the measured parameters. Similarly, weight change (both gain and loss) in our patients was not correlated with age $(\mathrm{p}=0.078)$, weight $(\mathrm{p}=0.063)$ or BMI $(\mathrm{p}=0.075)$. As these results approached significance, it allowed us to hypothesize that these groups of patients had a different probability of weight gain during breast cancer chemotherapy.

Despite this, there were no correlations between basal/final serum S1P and weight change or serum alanine and lactate (Table 2).

\section{Circulating S1P levels correlate with weight gain}

Our analysis on the set of 126 samples revealed that there were two groups of patients: those with lower levels of circulating S1P $(<8,2.17-6.19)$ who had an average weight gain of $1.77 \pm 0.72 \mathrm{~kg}$ and those with higher levels of circulating S1P (>8, 8.40-13.45), who had an average weight loss of $0.23 \pm 1.04 \mathrm{~kg}, \mathrm{p}=0.106$ (Fig. 1 A). Similarly, separating our patients by S1P/weight ratio demonstrated two distinct groups of patients, with low $(<10,3.80-8.26)$ and high (>10, 10.13-18.75) S1P/weight ratios who had $2.015 \pm 0.81 \mathrm{~kg}$ vs $-0.14 \pm 0.77 \mathrm{~kg}$ weight change respectively, $\mathrm{p}=0.049$ (Fig. 1 B). This revealed a significant correlation between dynamic normalised S1P levels and chemotherapy-induced weight change.

To identify the nature of the correlation of dynamic S1P to chemotherapy-induced weight change, we separated our patients into weight gain versus weight loss groups and plotted their relative S1P change versus weight change (Suppl. Fig. 1). In the majority of the patients 
with weight gain, a dynamic change in circulating S1P was inversely correlated with weight gain (Suppl. Fig. 1 A), whereas in patients with no gain or loss (Suppl. Fig. 1 B), circulating S1P change had no correlation with weight change.

Correlation analyses demonstrated that both $\mathrm{S} 1 \mathrm{P}$ and $\mathrm{S} 1 \mathrm{P} /$ weight ratio were significantly correlated with weight change only in patients who gained weight $(>1.5 \mathrm{~kg})$, but not in patients with no weight change $(< \pm 1.5 \mathrm{~kg})$, or weight loss $(<-1.5 \mathrm{~kg})$ (Table 3$)$.

To further corroborate and internally validate these findings, we then examined the circulating S1P and S1P/weight ratio in patients with small $(<3 \mathrm{~kg})$ versus large $(>3 \mathrm{~kg})$ weight gain. Patients with a large weight gain appeared to have extremely low serum S1P values and were significantly different from patients with small gain $(3.81 \pm 0.39$ vs 7.50 \pm 1.02 respectively, $\mathrm{p}=0.0073$ ) (Fig. 2 A). A similar pattern was observed in $\mathrm{S} 1 \mathrm{P} /$ weight ratio (4.83 \pm 0.32 vs $10.27 \pm 1.79$ respectively, p=0.0136) (Fig. 2 B). Comparing patients with high weight gain to the remainder (combined low weight gain, no change and weight loss), our data showed that their serum S1P was significantly lower $(3.81 \pm 0.39$ vs $7.00 \pm 0.87$ respectively, $\mathrm{p}=0.0369$ ) (Fig. $2 \mathrm{C}$ ). The same difference was observed in their S1P/weight ratio (4.83 \pm 0.32 vs $10.12 \pm 1.26$ respectively, $\mathrm{p}=0.0177)$ (Fig. $2 \mathrm{D})$. 


\section{Discussion}

In this current study we provide evidence that a loss in circulating S1P is correlated with weight gain in breast cancer patients treated with chemotherapy, suggesting a potential implication of circulating lipid second messengers in regulation of adipose tissue homeostasis during cancer progression.

While the influence of obesity on breast cancer outcome is well documented [40], its mechanisms have been poorly studied. Recent data suggest that adipose tissue secretes specific factors (adipokines) that may regulate cancer cell growth, angiogenesis and chemoresistance [41]. It is possible that an increased amount of fat tissue may be responsible for poorer survival in overweight breast cancer patients [10] and thus the weight gain observed during breast cancer chemotherapy may present an important clinical complication.

In this study we have correlated the levels of secreted lipid second messenger S1P with weight changes in women with breast cancer receiving chemotherapy. The fact that S1P is a regulatory lipid [42] suggests that its circulating levels may be involved in undetermined processes. While increase in circulating S1P was recently associated with inflammatory coronary artery disease [32] and cancer [34], its sources were unclear. With the baseline levels of circulating S1P being maintained by blood cells [28-31], it is conceivable that these levels may be altered by various pathological conditions or therapeutic interventions, which may in turn influence homeostasis at distant sites.

We have previously reported chemotherapy induced down-regulation of S1P and have found a chemotherapy-mediated SphK1 inhibition and S1P decrease in leukemia [43] and prostate cancer cells $[39,44]$. Importantly this phenomenon may be cell type- and chemotherapydependent since different chemotherapy was also shown to induce an increase in SphK1 
activity and S1P production in prostate cancer [44] pancreatic cancer [45] and leukemia cells [46]. In our current study, all patients were treated with the same chemotherapy (FEC), however the modification and dynamics of circulating S1P were not homogenous (15 cases of overall S1P decrease vs 6 cases of overall S1P increase; Suppl. Fig. 1). Furthermore we have found no clinical or metabolic correlates that would predict for a fall in circulating S1P in response to chemotherapy (no association with any of the factors in the paper [13]); we therefore hypothesise that there may be a genetic predetermination for such response.

In our study we have found that basal levels of circulating S1P were not prognostic for chemotherapy-induced weight change in women with breast cancer (Table 1). They were also not correlated to age, weight and BMI. Absence of a correlation between BMI and serum S1P also suggests that the contribution of S1P secreted from fat tissue to overall circulating S1P is not significant. Importantly, basal levels of circulating S1P were not correlated with serum levels of alanine and lactate (Table 2), which we have previously found to be prognostic for chemotherapy-induced weight gain [13].

Our data show that dynamic changes in serum S1P are inversely correlated specifically with chemotherapy-induced weight gain in women with breast cancer. Patients with lower S1P levels had higher weight gain than patients with higher S1P levels, patients who generally exhibited weight loss. Once again, this inverse correlation appeared to be specific for patients with weight gain, but not weight loss or no change (Suppl. Fig. 1, Table 3, Fig. 2), which suggests that the loss of circulating S1P is a prerequisite for an increase in adipose tissue. Importantly, the end levels of serum S1P have again not correlated with weight gain (Table 2). This indicates that it may be the dynamic changes in serum S1P that regulate the growth of adipose tissue. 
The role of S1P in adipose tissue homeostasis is still poorly studied, however recent evidence suggests a negative regulation of adipose homeostasis by $\mathrm{S} 1 \mathrm{P} / \mathrm{S} 1 \mathrm{P}$ receptor signaling. In differentiated rat white adipocytes $\mathrm{S} 1 \mathrm{P}$ was shown to significantly reduce insulin-induced mRNA of $o b$ gene and leptin secretion through an S1P receptors-mediated mechanism [47]. Additionally, genetic analyses have revealed S1P receptors as genes induced by dietary L-arginine (Arg) supplementation that leads to a reduction in white-fat gain in diet-induced obese rats [48].

Overall, in this study we have correlated a loss of circulating S1P with the weight gain in individuals with breast cancer receiving chemotherapy. We propose that circulating S1P may act as a repressive factor for the growth of adipose tissue.

Our study is limited by small numbers of patients (although the numbers of samples were large because of their sequential nature) and several analyses performed on the data, derived from a homogenous set of patients. Future studies are required to investigate the mechanism of regulation of adipose tissue during chemotherapy and to identify whether this mechanism has a broader context in regulating non-chemotherapy-induced obesity. This includes the prospective measurement of S1P levels in studies, including dietary interventions, that we now hope to undertake.

This has particular clinical importance in the context of several molecular therapies targeting SphK1/S1P pathway that are currently being developed. These include a first clinically applicable S1P antibody [49], which is currently undergoing several clinical trials including cancer trials and FTY720, an S1P receptor antagonist that has been recently published to be successful in phase III trials for treatment of MS $[50,51]$. In this context understanding the potential side effects of interfering with the SphK1/S1P pathway on various body systems 
including the adipose tissue homeostasis is of utter importance. Lowering of circulating S1P by chemotherapy or targeting therapy may switch S1P-mediated adipose cell stasis to cell growth and adipogenesis. 


\section{Acknowledgements}

This study was supported by: The Royal Society (grant number P24841 to DP), The Prostate

Cancer Charity (grant number 110630 to DP) and Prostate UK (grant number G2007/07 to DP). JS is supported by Ovarian Cancer Action. 
Figure legends

Figure 1. Dynamic S1P/weight ratio measured throughout chemotherapy cycles correlate with chemotherapy-induced weight change.

A, B. Circulating S1P was measured during chemotherapy and normalised to body weight at the time of measurement $(\mathbf{B})$. Average values are shown.

Columns, mean values; Bars, SEM; *, p<0.05;

Figure 2. Circulating S1P or S1P/weight ratio measured throughout the treatment cycle correlates with large weight gain.

A-D. Circulating S1P was measured during chemotherapy and normalised to body weight at the time of measurement $(\mathbf{B}, \mathbf{D})$. Average values are shown. Large gain - >3kg, small gain $1.5-3 \mathrm{~kg}$.

Columns, mean values; Bars, SEM; *, $<<0.05$; **, $\mathrm{p}<0.01$ 


\section{References}

1. Rock CL, Flatt SW, Newman V, Caan BJ, Haan MN, Stefanick ML, Faerber S, Pierce JP: Factors associated with weight gain in women after diagnosis of breast cancer. Women's Healthy Eating and Living Study Group. J Am Diet Assoc 1999, 99(10):1212-1221.

2. Demark-Wahnefried W, Peterson BL, Winer EP, Marks L, Aziz N, Marcom PK, Blackwell K, Rimer BK: Changes in weight, body composition, and factors influencing energy balance among premenopausal breast cancer patients receiving adjuvant chemotherapy. J Clin Oncol 2001, 19(9):2381-2389.

3. Dixon JK, Moritz DA, Baker FL: Breast cancer and weight gain: an unexpected finding. Oncol Nurs Forum 1978, 5(3):5-7.

4. Donegan WL, Hartz AJ, Rimm AA: The association of body weight with recurrent cancer of the breast. Cancer 1978, 41(4):1590-1594.

5. Huntington $\mathrm{MO}$ : Weight gain in patients receiving adjuvant chemotherapy for carcinoma of the breast. Cancer 1985, 56(3):472-474.

6. Goodwin PJ: Weight gain in early-stage breast cancer: where do we go from here? J Clin Oncol 2001, 19(9):2367-2369.

7. Chlebowski RT, Aiello E, McTiernan A: Weight loss in breast cancer patient management. J Clin Oncol 2002, 20(4):1128-1143.

8. Kroenke $\mathrm{CH}$, Chen WY, Rosner $\mathrm{B}$, Holmes MD: Weight, weight gain, and survival after breast cancer diagnosis. J Clin Oncol 2005, 23(7):1370-1378.

9. Caan BJ, Emond JA, Natarajan L, Castillo A, Gunderson EP, Habel L, Jones L, Newman VA, Rock CL, Slattery ML et al: Post-diagnosis weight gain and breast cancer recurrence in women with early stage breast cancer. Breast Cancer Res Treat 2006, 99(1):47-57.

10. Litton JK, Gonzalez-Angulo AM, Warneke CL, Buzdar AU, Kau SW, Bondy M, Mahabir S, Hortobagyi GN, Brewster AM: Relationship between obesity and pathologic response to neoadjuvant chemotherapy among women with operable breast cancer. J Clin Oncol 2008, 26(25):4072-4077.

11. Chlebowski RT, Blackburn GL, Thomson CA, Nixon DW, Shapiro A, Hoy MK, Goodman MT, Giuliano AE, Karanja N, McAndrew P et al: Dietary fat reduction and breast cancer outcome: interim efficacy results from the Women's Intervention Nutrition Study. J Natl Cancer Inst 2006, 98(24):1767-1776.

12. Pierce JP, Stefanick ML, Flatt SW, Natarajan L, Sternfeld B, Madlensky L, AlDelaimy WK, Thomson CA, Kealey S, Hajek R et al: Greater survival after breast cancer in physically active women with high vegetable-fruit intake regardless of obesity. J Clin Oncol 2007, 25(17):2345-2351.

13. Keun HC, Sidhu J, Pchejetski D, Lewis JS, Marconell H, Patterson M, Bloom SR, Amber V, Coombes RC, Stebbing J: Serum molecular signatures of weight change during early breast cancer chemotherapy. Clin Cancer Res 2009, 15(21):67166723.

14. Ogretmen B, Hannun YA: Biologically active sphingolipids in cancer pathogenesis and treatment. Nat Rev Cancer 2004, 4(8):604-616.

15. Mitra P, Oskeritzian CA, Payne SG, Beaven MA, Milstien S, Spiegel S: Role of ABCC1 in export of sphingosine-1-phosphate from mast cells. Proceedings of the National Academy of Sciences of the United States of America 2006, 103(44):1639416399.

16. Hla T: Signaling and biological actions of sphingosine 1-phosphate. Pharmacol Res 2003, 47(5):401-407.

17. Hla T, Lee MJ, Ancellin N, Paik JH, Kluk MJ: Lysophospholipids--receptor revelations. Science 2001, 294(5548):1875-1878. 
18. Payne SG, Milstien S, Spiegel S: Sphingosine-1-phosphate: dual messenger functions. FEBS Lett 2002, 531(1):54-57.

19. Xia P, Gamble JR, Rye KA, Wang L, Hii CS, Cockerill P, Khew-Goodall Y, Bert AG, Barter PJ, Vadas MA: Tumor necrosis factor-alpha induces adhesion molecule expression through the sphingosine kinase pathway. Proceedings of the National Academy of Sciences of the United States of America 1998, 95(24):1419614201.

20. Pettus BJ, Bielawski J, Porcelli AM, Reames DL, Johnson KR, Morrow J, Chalfant CE, Obeid LM, Hannun YA: The sphingosine kinase 1/sphingosine-1-phosphate pathway mediates COX-2 induction and PGE2 production in response to TNFalpha. Faseb J 2003, 17(11):1411-1421.

21. Sato K, Ishikawa K, Ui M, Okajima F: Sphingosine 1-phosphate induces expression of early growth response-1 and fibroblast growth factor-2 through mechanism involving extracellular signal-regulated kinase in astroglial cells. Brain research 1999, 74(1-2):182-189.

22. Bayerl MG, Bruggeman RD, Conroy EJ, Hengst JA, King TS, Jimenez M, Claxton DF, Yun JK: Sphingosine kinase 1 protein and mRNA are overexpressed in nonHodgkin lymphomas and are attractive targets for novel pharmacological interventions. Leuk Lymphoma 2008, 49(5):948-954.

23. French KJ, Schrecengost RS, Lee BD, Zhuang Y, Smith SN, Eberly JL, Yun JK, Smith CD: Discovery and evaluation of inhibitors of human sphingosine kinase. Cancer research 2003, 63(18):5962-5969.

24. Ruckhaberle E, Rody A, Engels K, Gaetje R, von Minckwitz G, Schiffmann S, Grosch S, Geisslinger G, Holtrich U, Karn T et al: Microarray analysis of altered sphingolipid metabolism reveals prognostic significance of sphingosine kinase 1 in breast cancer. Breast cancer research and treatment 2007.

25. Van Brocklyn JR, Jackson CA, Pearl DK, Kotur MS, Snyder PJ, Prior TW: Sphingosine kinase-1 expression correlates with poor survival of patients with glioblastoma multiforme: roles of sphingosine kinase isoforms in growth of glioblastoma cell lines. J Neuropathol Exp Neurol 2005, 64(8):695-705.

26. Li J, Guan HY, Gong LY, Song LB, Zhang N, Wu J, Yuan J, Zheng YJ, Huang ZS, Li M: Clinical significance of sphingosine kinase-1 expression in human astrocytomas progression and overall patient survival. Clin Cancer Res 2008, 14(21):6996-7003.

27. Li W, Yu CP, Xia JT, Zhang L, Weng GX, Zheng HQ, Kong QL, Hu LJ, Zeng MS, Zeng YX et al: Sphingosine kinase 1 is associated with gastric cancer progression and poor survival of patients. Clin Cancer Res 2009, 15(4):1393-1399.

28. English D, Welch Z, Kovala AT, Harvey K, Volpert OV, Brindley DN, Garcia JG: Sphingosine 1-phosphate released from platelets during clotting accounts for the potent endothelial cell chemotactic activity of blood serum and provides a novel link between hemostasis and angiogenesis. Faseb $J$ 2000, 14(14):2255-2265.

29. Yatomi Y, Ohmori T, Rile G, Kazama F, Okamoto H, Sano T, Satoh K, Kume S, Tigyi G, Igarashi Y et al: Sphingosine 1-phosphate as a major bioactive lysophospholipid that is released from platelets and interacts with endothelial cells. Blood 2000, 96(10):3431-3438.

30. Hanel P, Andreani P, Graler MH: Erythrocytes store and release sphingosine 1phosphate in blood. Faseb J 2007, 21(4):1202-1209.

31. Ohkawa R, Nakamura K, Okubo S, Hosogaya S, Ozaki Y, Tozuka M, Osima N, Yokota $\mathrm{H}$, Ikeda $\mathrm{H}$, Yatomi Y: Plasma sphingosine-1-phosphate measurement in healthy subjects: close correlation with red blood cell parameters. Annals of clinical biochemistry 2008, 45(Pt 4):356-363. 
32. Deutschman DH, Carstens JS, Klepper RL, Smith WS, Page MT, Young TR, Gleason LA, Nakajima N, Sabbadini RA: Predicting obstructive coronary artery disease with serum sphingosine-1-phosphate. Am Heart J 2003, 146(1):62-68.

33. Kawamori T, Osta W, Johnson KR, Pettus BJ, Bielawski J, Tanaka T, Wargovich MJ, Reddy BS, Hannun YA, Obeid LM et al: Sphingosine kinase 1 is up-regulated in colon carcinogenesis. Faseb $J$ 2006, 20 (2):386-388.

34. Sutphen R, Xu Y, Wilbanks GD, Fiorica J, Grendys EC, Jr., LaPolla JP, Arango H, Hoffman MS, Martino M, Wakeley K et al: Lysophospholipids are potential biomarkers of ovarian cancer. Cancer Epidemiol Biomarkers Prev 2004, 13(7):1185-1191.

35. Boneva-Asiova Z, Boyanov MA: Body composition analysis by leg-to-leg bioelectrical impedance and dual-energy $X$-ray absorptiometry in non-obese and obese individuals. Diabetes Obes Metab 2008.

36. Edsall LC, Spiegel S: Enzymatic measurement of sphingosine 1-phosphate. Anal Biochem 1999, 272(1):80-86.

37. Pchejetski D, Doumerc N, Golzio M, Naymark M, Teissie J, Kohama T, Waxman J, Malavaud B, Cuvillier O: Chemosensitizing effects of sphingosine kinase-1 inhibition in prostate cancer cell and animal models. Molecular cancer therapeutics 2008, 7(7):1836-1845.

38. Folch J, Lees M, Sloane Stanley GH: A simple method for the isolation and purification of total lipides from animal tissues. J Biol Chem 1957, 226(1):497509.

39. Pchejetski D, Golzio M, Bonhoure E, Calvet C, Doumerc N, Garcia V, Mazerolles C, Rischmann P, Teissie J, Malavaud B et al: Sphingosine kinase-1 as a chemotherapy sensor in prostate adenocarcinoma cell and mouse models. Cancer research 2005, 65(24):11667-11675.

40. Pischon T, Nothlings U, Boeing H: Obesity and cancer. The Proceedings of the Nutrition Society 2008, 67(2):128-145.

41. Vona-Davis L, Rose DP: Angiogenesis, adipokines and breast cancer. Cytokine \& growth factor reviews 2009, 20(3):193-201.

42. Takabe K, Paugh SW, Milstien S, Spiegel S: "Inside-out" signaling of sphingosine-1-phosphate: therapeutic targets. Pharmacol Rev 2008, 60(2):181195.

43. Bonhoure E, Pchejetski D, Aouali N, Morjani H, Levade T, Kohama T, Cuvillier O: Overcoming MDR-associated chemoresistance in HL-60 acute myeloid leukemia cells by targeting sphingosine kinase-1. Leukemia 2006, 20(1):95-102.

44. Sauer L, Nunes J, Salunkhe V, Skalska L, Kohama T, Cuvillier O, Waxman J, Pchejetski D: Sphingosine kinase 1 inhibition sensitizes hormone-resistant prostate cancer to docetaxel. International journal of cancer 2009.

45. Guillermet-Guibert J, Davenne L, Pchejetski D, Saint-Laurent N, Brizuela L, Guilbeau-Frugier C, Delisle MB, Cuvillier O, Susini C, Bou squet C: Targeting the sphingolipid metabolism to defeat pancreatic cancer cell resistance to the chemotherapeutic gemcitabine drug. Molecular cancer therapeutics 2009, 8(4):809-820.

46. Gude DR, Alvarez SE, Paugh SW, Mitra P, Yu J, Griffiths R, Barbour SE, Milstien $S$, Spiegel S: Apoptosis induces expression of sphingosine kinase 1 to release sphingosine-1-phosphate as a "come-and-get-me" signal. Faseb J 2008, 22(8):2629-2638.

47. Jun DJ, Lee JH, Choi BH, Koh TK, Ha DC, Jeong MW, Kim KT: Sphingosine-1phosphate modulates both lipolysis and leptin production in differentiated rat white adipocytes. Endocrinology 2006, 147(12):5835-5844. 
48. Jobgen W, Fu WJ, Gao H, Li P, Meininger CJ, Smith SB, Spencer TE, Wu G: High fat feeding and dietary $L$-arginine supplementation differentially regulate gene expression in rat white adipose tissue. Amino Acids 2009, 37(1):187-198.

49. Visentin B, Vekich JA, Sibbald BJ, Cavalli AL, Moreno KM, Matteo RG, Garland WA, Lu Y, Yu S, Hall HS et al: Validation of an anti-sphingosine-1-phosphate antibody as a potential therapeutic in reducing growth, invasion, and angiogenesis in multiple tumor lineages. Cancer Cell 2006, 9(3):225-238.

50. Cohen JA, Barkhof F, Comi G, Hartung HP, Khatri BO, Montalban X, Pelletier J, Capra R, Gallo P, Izquierdo $\mathrm{G}$ et al: Oral fingolimod or intramuscular interferon for relapsing multiple sclerosis. The New England journal of medicine, 362(5):402415.

51. Kappos L, Radue EW, O'Connor P, Polman C, Hohlfeld R, Calabresi P, Selmaj K, Agoropoulou C, Leyk M, Zhang-Auberson L et al: A placebo-controlled trial of oral fingolimod in relapsing multiple sclerosis. The New England journal of medicine, 362(5):387-401. 